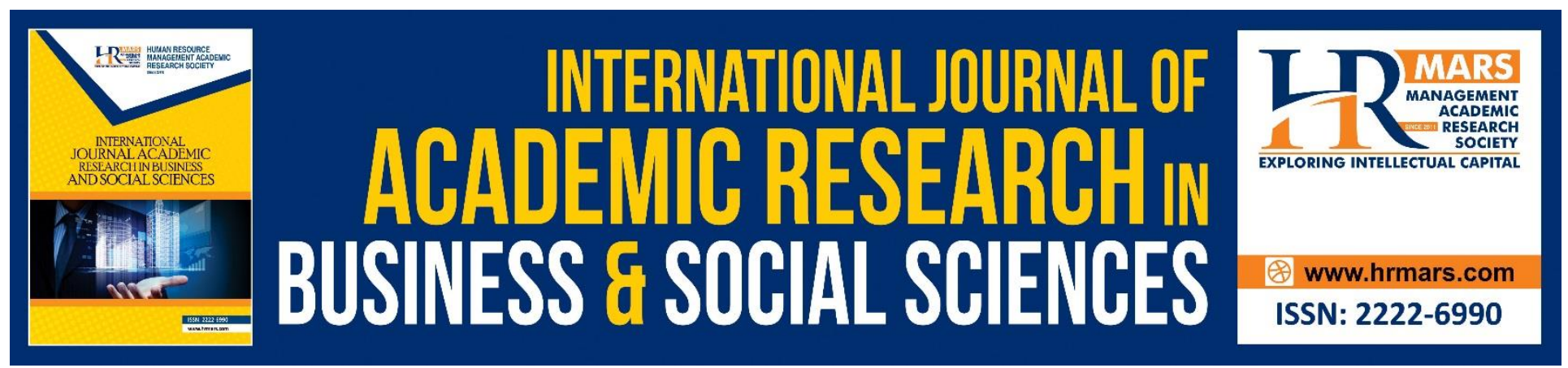

\title{
The Influence of Employees Job Related Characteristics and Psychological Capital towards Trust Management
}

Norhayati Yaacob, Maimunah Mohd Shah, Idaya Husna Mohd, Norashikin Hussein, Muhamad Khalil Omarm, Mohd Syamim Che Muhamad Hariri

To Link this Article: http://dx.doi.org/10.6007/IJARBSS/v8-i11/5563 DOI: $10.6007 /$ IJARBSS/v8-i11/5563

Received: 06 Oct 2018, Revised: 18 Nov 2018, Accepted: 19 Nov 2018

Published Online: 25 Nov 2018

In-Text Citation: (Yaacob et al., 2018)

To Cite this Article: Yaacob, N., Shah, M. M., Mohd, I. H., Hussein, N., Omarm, M. K., \& Hariri, M. S. C. M. (2018). The Influence of Employees Job Related Characteristics and Psychological Capital towards Trust Management. International Journal of Academic Research in Business and Social Sciences, 8(11), $1995-2007$.

Copyright: (C) 2018 The Author(s)

Published by Human Resource Management Academic Research Society (www.hrmars.com)

This article is published under the Creative Commons Attribution (CC BY 4.0) license. Anyone may reproduce, distribute, translate and create derivative works of this article (for both commercial and non-commercial purposes), subject to full attribution to the original publication and authors. The full terms of this license may be seen

at: $\underline{\text { http://creativecommons.org/licences/by/4.0/legalcode }}$

Vol. 8, No. 11, 2018, Pg. 1995 - 2007

Full Terms \& Conditions of access and use can be found at http://hrmars.com/index.php/pages/detail/publication-ethics 


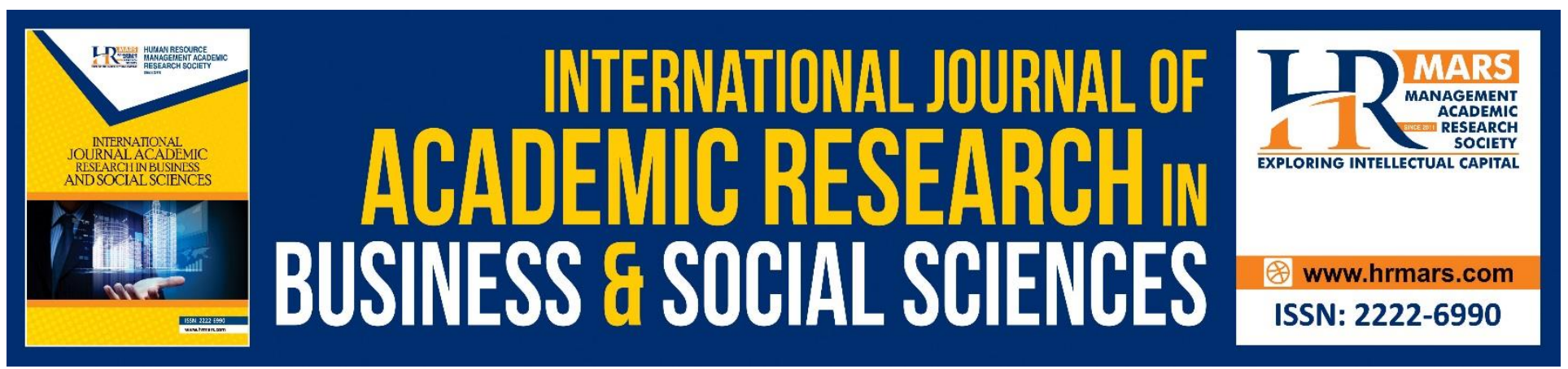

\title{
The Influence of Employees Job Related Characteristics and Psychological Capital towards Trust Management
}

\author{
Norhayati Yaacob, Maimunah Mohd Shah, Idaya Husna Mohd, \\ Norashikin Hussein, Muhamad Khalil Omarm, Mohd Syamim Che \\ Muhamad Hariri \\ Faculty of Business and Management, Universiti Teknologi, MARA, (UiTM) Selangor, Malaysia.
}

\begin{abstract}
Employee's attitudes and behaviors are the key factors to achieve the goals of an organization. Changes happened in the organization caused by human, cost, organizational structure and environment. Thus, the main purpose of this study is to examine the relationship between employees' job-related characteristics and psychological capital towards trust in management. The study was conducted in Selangor and the organization is in the process of managing change. Survey questionnaires were used to collect data and 155 cases were analyzed. The findings show that employees' job-related characteristics and psychological capital have significantly related towards trust in management. Furthermore, the results indicate that the most influential factor after doing the multiple regression analysis is optimism which is one of psychological capital dimensions. It is recommended that the results can be used as a reference to any private or government sector in order for them to initiate an organizational change within the company.
\end{abstract}

Keywords: Attitude, Behavior, Organizational Structure, Environment

\section{INTRODUCTION}

Research findings have indicated that trust in management to change is extremely affected by employees' job-related characteristics and psychological capital (Weber and Weber, 2001; Saruhan, 2013). Trusting communication can overcome the problem of lack of information and reduce feelings of uncertainty, speculation and unfounded fears during the process of change. In order to establish the long-term relationship, the organization will experience high turnover in dealing with the complexities of competitive business market (Burke and Stet, 1999). When trust in management is low, this will give negative impact towards the organizational performance because the process for change would appear as a suspicious and threatening process (Saruhan, 2013). As aforementioned, employees' job-related characteristics and positive psychological capital may be correlated with trust during the process of organizational change. There are several important employees' job-related 
characteristics that have been identified with success in organizational change, such as feedback, autonomy, employee participation, skill variety, task identity, task significance and goal clarity [Weber and Weber, 2001, Katsaros, Tsirikas, and Bani, 2014] and psychological capital (i.e. selfefficacy, optimism, hope and resiliency) (Saruhan, 2013; Clapp-Smith, Vogelgesang, and Avey, 2009). Both job-related characteristics and psychological capital are able to help the organization promote innovation and change.

The empirical studies show that there are differences between before and after the initiation of process planned through collection of longitudinal data. The study conducted by Weber and Weber, 2001proved that a significant difference can be seen five months after the time that the data was collected, where the attitudes vary in the early stages. Thus, this study will examine all the variables and the findings may contribute to better understanding of how the process of organizational change can be more successful.

\section{LITERATURE REVIEW}

Employees' job-related characteristics are some of the human-related problems that the organization needs to consider when planning organizational changes. Such characteristics could affect human emotions, which include employees' perceptual and attitudinal characteristics (Katsaros and Nicolaidis, 2012). Thus, there are significant relationships among these variables. Other studies have proposed that positive psychological capital will contribute to the positive changes for the organization. It could reduce any resistance to change among employees, as emphasized by Oreg's dispositional resistance to change theoretical framework. Saruhan, 2013 proposed that people will show a variety of responses towards change implementations, which can be negative, positive, or neutral. Such responses are often mixed with personal commitments, promises and unspoken expectations in order to build a mutual understanding between the employee and the employer (Emre, Artan, Sisman, 2011).

Job-Related Characteristics: A job-related characteristic is defined by McShane and Von Glinow, 2009 as characteristics relating to the motivational properties of jobs to specific personal and organizational consequences of those properties. In the job characteristics model (JCM), the core job dimensions have been identified as autonomy, feedback, skill variety, task identity, task significance (Hackman and Oldman, 1976) and goal clarity (Bang et al., 2010).

Psychological Capital: Psychological capital is defined as an individual's positive psychological state of development that can be characterized by self-efficacy, optimism, hope and resiliency. Thus, it was suggested that psychological capital is another factor that could potentially influence trust in management during an organizational change (Saruhan, 2013). This study will explore more of the core of this variable via self-efficacy, optimism, hope and resiliency.

Trust in Management: Trust in management reflects the employees' enthusiasm regarding their jobrelated working environment (Tan and Lim, 2009). Trust in management becomes the most important factor that may contribute towards organizational success if the organization wants to 
sustain success in the long-term and to keep surviving in the current complex economy. Based on the literature review, trust can be categorized as "trust in organization" (employee-organization), "trust in supervisor" (employee-supervisor) and "trust in co-worker" (employee-employee). In this context, if employees do not have the full trust of the organization, they may feel insecure and uncertain, which will then create mistrustful feelings towards supervisors and co-workers (Saruhan, 2013).

\section{CONCEPTUAL FRAMEWORK}

The conceptual framework for this study explains employees' job-related characteristics and psychological capital that could potentially influence trust in management at the selected private company (Figure 1). This theoretical structure will illustrate how two independent variables correlate with a dependent variable. The consequences, together with the assumptions, principles and rules that support the previous results obtained by previous researchers will be discussed further. The independent variables represent the factors that the researcher can control to test the effects on particular outcomes. This study will examine the employees' job-related characteristics, namely goal clarity, feedback, autonomy and psychological capital, characterized as self-efficacy, optimism, hope and resiliency, as independent variables that may influence trust in management in the organization.

The conceptual framework between employees' job-related characteristics and trust in management has been proven by Weber and Weber, 2001; Katsaros, Tsirikas, and Bani, 2014. They had focused on the impact of planned change efforts on specific employee job-related attitudes and perceptions. However, the influence of psychological capital on trust in management has been proven from studies conducted by Saruhan, 2013 and Clapp-Smith, Vogelgesang, andAvey (2009). The dependent variable will represent the measure that reflects the outcome of the independent variables. The results of the dependent variable will be significantly influenced by the independent variables, which is the aim of this study. Thus, trust in management will be the independent variable in this relationship. This study will further explore the relationships between employees' job-related characteristics, psychological capital and trust in management.

\begin{tabular}{|c|c|}
\hline Independent Variables & $\begin{array}{c}\text { Dependent } \\
\text { Variable }\end{array}$ \\
\hline $\begin{array}{l}\text { Job related characteristics } \\
\text { - Goal Clarirty } \\
\text { - Feedback } \\
\text { - Autonomy } \\
\text { Psychological capital } \\
\text { - Self-efficacy } \\
\text { - Optimism } \\
\text { - Hope } \\
\text { - Resiliency }\end{array}$ & $\begin{array}{c}\text { Trust in } \\
\text { Management }\end{array}$ \\
\hline
\end{tabular}

Figure 1: Conceptual Framework 


\section{RESEARCH METHODOLOGY}

Data collection was done by using a set of questionnaires which were already distributed to the respondents in a selected private company in Selangor. A set of questions were adapted and adopted from a few recent studies carried out by previous researchers concerning the relationship between employees' job characteristics, psychological capital and trust in management. The questionnaire was developed from a pre-formulated set of written questions about the variables that are to be measured in the actual study (Sekaran, 2016). Factors such as the appropriateness of the questions, choice of words, the level of language used, sequencing of the questions and demographic information about the respondents had been considered in the process of developing the questionnaire. Dual language of English and Malay was used to cater to the different backgrounds of the respondents.

A cover letter had been attached to each set of the questionnaires which explained the purpose and objective of the research. It also provided instructions on how respondents should answer the questions, the confidentiality of each response given by the respondents and the contact numbers and e-mail addresses of the researcher. At the top section of the cover letter, a small box was displayed to indicate the number of questionnaire distributed to the respondents. This helped in the process of collection, where the respondent was able to keep track of which questionnaire had been answered by the respondents and which ones had not. The entire questionnaire has been divided into four sections, which consist of five pages for respondents to answer in total.

In Section A, the questions were structured to obtain the demographic profile of the respondents such as gender, age, marital status, highest level of education, level of management, department and working experience. The respondents were provided with multiple choice answers which allowed them to choose one answer only. However, the researcher had included 'Others' for the highest level of education and department, which allowed respondents to give another answer other than as listed. Some of the demographic profile had been adjusted with suitable terms to ensure that the respondents understood the questions given.

In Section B, the questions were designed to obtain feedback from respondents about employee jobrelated characteristics. This section consists of 13 out of 29 questions that had been adopted from Weber and Weber (2001) and adjusted accordingly. There were three sub-variables tested by the researcher which included goal clarity, autonomy and feedback. Each variable consists of between four to five questions. The questions had been organized with proper sequencing and the structure of each question had been revised and amended to be simple structure content.

In Section C, the questions were designed to identify the answers related to psychological capital. This section consists of 19 questions which were adopted from two different sources. The sub-variables consist of 14 out of 22 questions on resiliency, self-efficacy and optimism that were adopted from (Saruhan, 2013). The other sub-variable of hope was adopted from [20] with 5 instead of 24 questions. Some of the questions adopted from these sources had been revised and amended to simple structure content because it consists of some idioms that may not be understood by the respondents. 
In Section $D$, the questions were designed to identify the respondents' feedback regarding trust in management. This section consists of 4 out of 29 questions that were adopted from Weber and Weber, (2001). The questions were simple and just a few amendments on certain terms had been made to be included in the actual study. The necessary references and citations had been included at the bottom of every section to indicate the original source from which the questions were adopted.

Based on the sources above, the questionnaire was developed using different sets of Likert scales. The researcher finally decided to use only 5-point Likert Scale, being 1=Strongly Disagree, 2=Disagree, $3=$ Neutral, 4=Agree and 5=Strongly Agree, to observe the feedback given by the respondents for each variable in the study. This is to avoid confusing answers given by the respondents and to standardise the measurement to be done by the researcher when analysing the data collection in the actual study. In addition, the questions were designed to be closed-ended questions in order to provide some choices to the respondents to answer the questions.

The validity of instrument is a very important element to be considered before the questionnaire can be distributed to the respondents in the actual study. Validity refers to the quality of the test in doing what it has been designed to do or in measuring what it is supposed to measure (Salkind, 2006). The validity process was conducted to ensure that the questionnaire can be easilyunderstood by the respondents. Although the questionnaire was developed from a few previous studies, the content and structure of the questions can potentially affect the answers given by the respondents. Thus, the validity of instrument was tested for both content and face validity. According to Sekaran, (2006) the content validity is measured by the adequacy and representativeness of the set of items to tap the concept, while the face validity is measured by a basic and minimum index of content validity.

In order to ensure that the questionnaire designed by the researcher is acceptable to be distributed, two experts from the Faculty of Business and Management were selected to check and validate the content and face validity of the questionnaires. They were selected based on their Human Resources working background. Several comments were received about the questions in section $B$ and some minor corrections were made for section $C$. The researcher had also provided explanations and justifications on the several questions asked by the panel before making the necessary amendments afterwards.

After the questionnaire had been modified and approved by the expert panel, the researcher ran a pilot test to test the face validity of the questionnaire. The researcher decided to distribute approximately 100 sets of the questionnaire to random respondents from different companies in Selangor. The purpose of conducting the pilot test is to ensure that the items or statements can be fully understood by respondents. Other than that, it is also to ensure that the language used is simple and clear. In fact, it is also to test that the items are measuring what they are supposed to measure in the actual study. As a result, the researcher managed to collect all the questionnaires within two weeks and started to analyze the feedback from the respondents. 


\section{FINDINGS AND DATA ANALYSIS}

Demographic Background: Based on Table 1, the respondents of this study were from the selected private company in Selangor. 155 questionnaires were collected out of 200 questionnaires distributed, giving a response rate of $77 \%$. For the gender of the respondents, results showed that $49(32 \%)$ of the respondents were male and $106(68 \%)$ of the respondents were female. So from the result, it can be summarized that the number of female respondents is greater than male respondents. Secondly, for the marital status of the respondents, the result showed that $57(37 \%)$ of the respondents were single, $93(60 \%)$ of the respondents were married and $5(3 \%)$ of the respondents were divorced. Thirdly, for the age of respondents, it can be summarized that most of the respondents are aged between 21 to 30 years old, with 82 out of 155 respondents (53\%) being junior employees. There is less participation from senior employees compared to junior employees (by 3\%). The age group of senior employees is between 51 to 60 years old. Forth, regarding the level of education in the present workplace, 59 of them (38\%) are diploma holders. This indicates that the majority of employees who work at the selected private company have middle level education. However, only 5 respondents (3\%) have completed their education up to Master level. Fifth, regarding the question respondent's level of management, it was found that the highest number, being 96 of 155 respondents (62\%) comes from group middle level management. This group consists of Executives, Senior Executives, Assistant Managers and Managers. Meanwhile, only 3 respondents (2\%) who participated in this study are from top level management which comes from three different departments in a selected private company. Findings showed the number of years that each respondent has worked at the selected private company. Most of the respondents, namely 72 out of 155 (46\%) respondents, are employees who have worked with the company for between 5 to 10 years. Meanwhile, 7 of 44the respondents (5\%) have worked with the company for between 21 to 30 years, which is only a small number. 
INTERNATIONAL JOURNAL OF ACADEMIC RESEARCH IN BUSINESS AND SOCIAL SCIENCES

Vol. 8, No. 11, Nov, 2018, E-ISSN: 2222-6990 @ 2018 HRMARS

\begin{tabular}{|c|c|c|c|}
\hline & Variables & Frequency & Percent (\%) \\
\hline \multirow[t]{2}{*}{ Gender } & Male & 49 & 32 \\
\hline & Female & 106 & 68 \\
\hline \multirow[t]{4}{*}{ Age } & 21 - 30 years old & 82 & 53 \\
\hline & $31-40$ years old & 58 & 37 \\
\hline & 41 - 50 years old & 10 & 7 \\
\hline & $51-60$ years old & 5 & 3 \\
\hline \multirow[t]{5}{*}{ Marital Status } & SPM & 39 & 25 \\
\hline & STPM & 8 & 6 \\
\hline & Diploma & 59 & 38 \\
\hline & Degree & 44 & 28 \\
\hline & Master & 5 & 3 \\
\hline Respondent's Higher & Less than 1 year & 32 & 36 \\
\hline \multirow[t]{3}{*}{ Level Education } & $1-5$ years & 36 & 21 \\
\hline & $6-10$ years & 21 & 10 \\
\hline & 11 years and above & 11 & \\
\hline Respondent's Level of & Lower & 56 & 36 \\
\hline \multirow[t]{2}{*}{ Management } & Middle & 96 & 62 \\
\hline & Top & 3 & 2 \\
\hline \multirow[t]{4}{*}{ Working Experience } & Less than 5 years & 53 & 34 \\
\hline & $5-10$ years & 72 & 46 \\
\hline & $11-20$ years & 23 & 15 \\
\hline & $21-30$ years & 7 & 5 \\
\hline
\end{tabular}

Table 1: Demographic Profile $(\mathrm{N}=155)$

Reliability Analysis: Reliability analysis was conducted after factor analysis and it was carried out to measure consistency of the instrument in measuring the constructs. According to Sekaran, (2006), the instruments are reliable when Cronbach's alpha values are above .70 and closer to 1.0. But Kerlinger and Lee (2000) stated that for social science research .50 to .60 are still acceptable. It means that when the value is higher, the internal consistency reliability is also high. The respective alpha coefficients for the present study are between $\alpha=.776$ and $\alpha=.886$ which show high degree of reliability (Table 2).The lowest alpha value is .776 (self-efficacy) and the highest alpha value is .878 (hope). The reliability analyses also indicate that there are high reliability coefficients for all dependent variable items with Cronbach's Alpha value exceeding .886. All values are acceptable and there are high internal consistencies exceeding Nunnally's (Nunnally, 1978) threshold of .70. Hence, the analyses show that there are high internal consistency and stability, which allow the researcher to proceed with analysis. 
INTERNATIONAL JOURNAL OF ACADEMIC RESEARCH IN BUSINESS AND SOCIAL SCIENCES

Vol. 8, No. 11, Nov, 2018, E-ISSN: 2222-6990 @ 2018 HRMARS

\begin{tabular}{lcc}
\hline Variables & Cronbach & $\#$ \\
\hline Job-Related Characteristic & .818 & 4 \\
Job-Related Characteristic & .808 & 5 \\
Job-Related Characteristic & .780 & 4 \\
Psychological Capital & .792 & 6 \\
Psychological Capital Self- & .776 & 4 \\
Psychological Capital Hope & .878 & 5 \\
Psychological Capital & .855 & 4 \\
Trust in Management & .886 & 4 \\
\multicolumn{1}{c}{ Total of Questions } & & 36 \\
\hline
\end{tabular}

Table 2: Cronbach's Alpha Scores for Employee Job-Related Characteristics, Psychological Capital and Trust in Management.

\section{Hypotheses Development}

There are three hypotheses developed in this article:

$\mathrm{H} 1$ Job-Related Characteristics has a significant impact on Trust in Management

H2 Psychological Capital has a significant impact on Trust in Management

H3 All dimensions in job-related characteristics have significant relationships with trust in management.

Multiple regressions are conducted to further determine the results on the relationship between employees' job-related characteristics, psychological capital and trust in management. The regression results shown in Table 3 indicate that $36 \%$ of the variance in dependent variables of trust in management is explained by job-related characteristics and psychological capital. The adjusted $\mathrm{R}^{2}=0.351$ with $\mathrm{R}^{2}=0.359$ shows that there is a linear regression between the variables. It proved that there is a highly significant relationship, as indicated by the F-value of 42.621 in the above table. Furthermore, the analysis results show Durbin-Watson value $(\mathrm{d}=1.725)$ as falling is between the two critical values of 1.5 and 2.5 , otherwise represented as $1.5<d<2.5$. Therefore, the alternate hypotheses $\left(\mathrm{H}_{1}\right.$ and $\left.\mathrm{H}_{2}\right)$ developed are supported. The job-related characteristics and psychological capital have a high significant impact on trust in management. However, it is found that job-related characteristics is not the most influential variable upon trust in management (Sig. .000; $6,0.318$ ) and $\mathrm{H}_{3}$ is rejected. Although the results indicate that these two independent variables have a significant relationship, psychological capital is the strongest variable. 
INTERNATIONAL JOURNAL OF ACADEMIC RESEARCH IN BUSINESS AND SOCIAL SCIENCES

Vol. 8, No. 11, Nov, 2018, E-ISSN: 2222-6990 @ 2018 HRMARS

\begin{tabular}{lcc}
\hline \multicolumn{1}{c}{ Model } & Standardized Coefficients(Beta) & Sig. \\
Job-Related Characteristics & 0.318 & 0.000 \\
Psychological Capital & 0.345 & 0.000 \\
$\mathrm{R}^{2}$ & 0.359 & \\
Adjusted $\mathrm{R}^{2}$ & 0.351 & \\
F Value & 42.621 & \\
Significance F Value & 0.000 & \\
Durbin-Watson & 1.725 & \\
\hline
\end{tabular}

Table 3: Multiple Regression between Employees' Job-Related Characteristics, Psychological Capital

Based on Table 4, it shows multiple regressions are conducted to determine the relationship between all dimensions of independent variables with dependent variables. The regression results in Table 4 revealed that $47 \%$ of the variance in trust in management is explained by all dimensions in job-related characteristics and psychological capital. The adjusted $R^{2}=0.474$ with $R^{2}=0.449$ show that there is a linear regression between the variables. It proves the existence of a highly significant relationship, as indicated by the F-value of 18.940 in the above table. Furthermore, the analysis results show DurbinWatson value $(d=1.760)$, which fall between the two critical values of $1.5<d<2.5$. The goal clarity and optimism have a high significant impact on trust in management with Sig. value of less than 0.05 $(p<0.05)$. However, the study reveals that optimism is variable which has the strongest influence on trust in management (Sig. .000; $6,0.417)$.

\begin{tabular}{|l|c|c|}
\hline \multicolumn{1}{|c|}{ Model } & $\begin{array}{c}\text { Standardized } \\
\text { coefficient } \\
\text { (Beta) }\end{array}$ & Sig. \\
\hline Goal Clarity & 0.331 & 0.000 \\
\hline Autonomy & 0.012 & 0.878 \\
\hline Feedback & 0.068 & 0.377 \\
\hline Resiliency & -0.107 & 0.223 \\
\hline Self-Efficacy & 0.045 & 0.626 \\
\hline Hope & 0.061 & 0.571 \\
\hline Optimism & 0.417 & 0.000 \\
\hline R & 0.474 & \\
\hline Adjusted R & 0.449 & \\
\hline F Value & 18.940 & \\
\hline $\begin{array}{l}\text { Significance F } \\
\text { Value }\end{array}$ & 0.000 & \\
\hline $\begin{array}{l}\text { Durbin- } \\
\text { Watson }\end{array}$ & 1.760 & \\
\hline
\end{tabular}

Table 4: Multiple Regression between All Variables in Employees' Job-Related Characteristics, Psychological Capital towards Trust in Management 


\section{CONCLUSION}

Findings of this study have shown that employees' job-related characteristics and psychological capital have significant impact on trust in management. It was found that employees with positive psychological capital have high levels of trust towards the management in the private company. With this relationship, the employees were very optimistic in giving their positive contributions to the organization if the management treats them well. In fact, positive human attitudes are important factors that can ease the implementation of change in the organization in the future. This study also found that employee attitudes play important roles in determining the goal of the organization. This situation refers to employees' job-related characteristics, such as goal clarity, feedback, and autonomy towards management. Employees will react positively if organizational goals, policies and procedures are clearly explained by the management. The management should also offer feedbacks on the results of post-implementation. However, based on the results, autonomy was not an influential factor towards organizational trust, but it was a significant relationship in the study.

\section{RECOMMENDATIONS}

The findings showed that employees' job-related characteristics and psychological capital have significant impacts on trust in management. In fact, a positive psychological capital among the employees will ease the implementation of any changes within the organization. Even though resiliency did not show a highly significant impact on trust in management, the employees had still observed all possible circumstances that might affect their trust in the organization. When they trust their management to achieve the organizational goal, the employees will feel more secure to stay with the company. Their trust is supported with highly optimistic attitudes towards the new implementation that the management plans to sustain the company. Meanwhile, employees' jobrelated characteristics have also shown a significant relationship with trust in management. Initially, three variables were tested in this study, namely, goal clarity, feedback and autonomy.

Furthermore, agoal clarity is important to gain the benefits of the changes made in the organization. It is also important for the management of human readiness to accept the changes to achieve the organizational objectives. Even though autonomy did not have a highly significant impact on trust in management, it could still influence the management based on certain circumstances. The organization should know how to utilize employees' dependency in managing their job tasks well. Autonomy might not have been a highly significant factor in this study because the employees felt that they can work without assistance from the management and did not give much impact towards the organizational goals.

\section{ACKNOWLEDGMENT}

The authors would like to acknowledge Faculty of Business and Management for funding the study. We also acknowledge the private company in Selangor for their willingness to provide the necessary information. 
INTERNATIONAL JOURNAL OF ACADEMIC RESEARCH IN BUSINESS AND SOCIAL SCIENCES

Vol. 8, No. 11, Nov, 2018, E-ISSN: 2222-6990 (C) 2018 HRMARS

\section{Corresponding Author}

Dr Maimunah Mohd Shah, Associate Professor

Faculty of Business and Management

Universiti Teknologi MARA, Selangor Branch

Puncak Alam Campus, 43200 Selangor, Malaysia

Email: maimu697@puncakalam.uitm.edu.my

\section{REFERENCES}

Avey, J., Reichard, R., Luthans, F., \& Mhatre, K. (2011). Meta-analysis of the impact of positive psychological capital on employee attitudes, behaviors, and performance. Human Resource Development Quarterly, 22(2), 127-152.

Bang, H., Fuglesang, S. L., Ovesen, M. R., \& Eilertsen, D. E. (2010). Effectiveness in top management group meetings: The role of goal clarity, focused communication, and learning behavior. Scandinavian Journal of Psychology, 51(3), 253-261.

Burke, P. J., \& Stets, J. E. (1999). Trust and commitment through self-verification. Social Psychology Quarterly, 347-366.

Clapp-Smith, R., Vogelgesang, G. R., \& Avey, J. B. (2009). Authentic leadership and positive psychological capital the mediating role of trust at the group level of analysis. Journal of Leadership \& Organizational Studies,15(3), 227-240.

Emre, I. S. C. I., Artan, I. E., \& Sisman, F. A. (2011). Role of Trust In Violation Of Psychological Contract's Effect on Organizational Citizenship Behaviour And Turnover Intention: A Research In Health Sector. International Journal of Business and Social Research, 1(1), 1-19.

Faraji, O., Ramazani, A. A., Hedaiati, P., Aliabadi, A., Elhamirad, S., \&Valiee, S. (2015). Relationship Between Job Characteristics and Organizational Commitment: A Descriptive Analytical Study. Iranian Red Crescent Medical Journal, 17(11).

Hackman, J. R., \& Oldham, G. R. (1976). Motivation through the design of work: Test of a theory. Organizational behavior and human performance, 16(2), 250-279.

Katsaros, K. K., \& Nicolaidis, C. S. (2012). Personal traits, emotions, and attitudes in the workplace: Their effect on managers' tolerance of ambiguity. The Psychologist-Manager Journal, 15(1), 37-55.

Katsaros, K. K., Tsirikas, A. N., \& Bani, S. M. N. (2014). Exploring employees' perceptions, job-related attitudes and characteristics during a planned organizational change. Int. Journal of Business Science and Applied Management, 9(1).

Kerlinger, F. N. and H. B. Lee, 2000. Foundations of behavioral research. Belmont, Calif.: Wadsworth.

McShane, S. L., \& Von Glinow, M. A. (2009). Organizational Behavior: Essemtols.

Nunnally, J. C., (1978), Psychometric Theory, McGraw-Hill, New York.

Salkind, N.J., (2006), "Exploring Research". (6th Ed.). Upper Saddle River New Jersey: Pearson Education, Inc.

Saruhan, N. (2013). Organizational Change: The Effects Of Trust In Organization and Psychological Capital During Change Process. Journal of Business Economics and Finance, 2(3), 13-35. 
Sapyaprapa, S., Tuicomepee, A., \&Watakakosol, R. (2013). Validation of Psychological Capital Questionnaire in Thai Employees. In The Asian Conference on Psychology and the Behavioral Sciences. p394-400.

Sekaran, U., (2006). "Research Methods for Business: A Skill Building Approach". (6th Ed.). John Wiley \& Sons, New York, N.Y.

Shukla, A., \& Rai, H. (2015). Linking Perceived Organizational Support to Organizational Trust and Commitment: Moderating Role of Psychological Capital. Global Business Review, 16(6), 981996.

Tan, H. H., \& Lim, A. K. (2009). Trust in coworkers and trust in organizations. The Journal of Psychology, 143(1), 45-66.

Weber, P. S., \& Weber, J. E. (2001). Changes in employee perceptions during organizational change. Leadership \& Organization Development Journal, 22(6), 291-300. 